\title{
Implication Of Character Traits In Adherence To Treatment In People With Gout: A Reason For Considering Nonadherence As A Syndrome
}

This article was published in the following Dove Press journal: Patient Preference and Adherence

\author{
Gérard Reach $\mathbb{1 D}^{1,2}$ \\ Gaëlle Chenuc ${ }^{3}$ \\ Pascal Maigret ${ }^{4}$ \\ Isabelle Elias-Billon ${ }^{4}$ \\ Luc Martinez (iD ${ }^{5}$ \\ René-Marc Flipo 6 \\ 'Department for Endocrinology, \\ Diabetes and Metabolic Diseases, \\ Avicenne Hospital, APHP, Bobigny, \\ France; ${ }^{2}$ Health Education and Practices \\ Laboratory (LEPS, EA 34I2), Paris 13 \\ University, Sorbonne Paris Cité, Bobigny, \\ France; ${ }^{3}$ Capionis Research, Bordeaux, \\ France; ${ }^{4}$ Medical Department, Menarini, \\ Rungis, France; ${ }^{5}$ Family Practice, La \\ Rochelle, France; ${ }^{6}$ Department of \\ Rheumatology, University Hospital, Lille, \\ France
}

\begin{abstract}
Objective: Various aspects of nonadherence to therapy (including medication and lifestyle nonadherence) often appear together. Here we report the association between treatment adherence in gout and the two character traits of patience and obedience, which may explain this observation.
\end{abstract}

Methods: Data were collected from a cross-sectional study conducted in a French cohort of 1441 adult patients. Patience was assessed using the choice between receiving $€ 1500$ in 1 year or $€ 500$ immediately. Obedience was evaluated with a single question assessing the use of the seatbelt in the rear seat of a car. Adherence to recommendations for medication, beverage, food and physical activity and smoking status was assessed using self-report questionnaires.

Results: Patience and obedience were strong determinants of adherence to medication in multivariate analysis (OR 2.056, 95\% CI [1.414-2.989], $P<0.001$; OR 1.844, 95\% CI [1.273-2.671], $P=0.001)$. In univariate analysis, adherence to medication was also associated with compliance with dietary directives $(P<0.001)$, lower alcohol consumption on an ordinary day $(P<0.001)$, never consuming soda $(P<0.001)$ or beer $(P<0.001)$, practice of physical activity $(P=0.002)$, being a nonsmoker $(P<0.001)$ and monitoring serum levels of uric acid regularly $(P=0.011)$. Multiple-correspondence analysis illustrated the associations of these different aspects of adherence (medication, diet and exercise, smoking status and monitoring of disease control) with patience and obedience. Finally, we observed a link between patience and obedience $(P<0.001)$.

Conclusion: Character traits, which shape preferences, may cause the clustering of different aspects of nonadherence in the form of a syndrome, elucidating the still enigmatic link between nonadherence to placebo and mortality in randomised clinical trials. This concept may also explain, at least in part, the difficulty of improving adherence to long-term therapies and may lead to ethical issues.

Keywords: adherence, patience, obedience, nonadherence syndrome, character traits, gout

\section{Introduction}

Nonadherence, defined as a lack of concordance between patients' behaviours and medical prescriptions, is a major issue in the care of chronic diseases. ${ }^{1}$ This concerns not only medication but also lifestyle changes. Different aspects of treatment adherence often appear together: for example, people adherent to statin therapy were found to be more likely to engage in a broad spectrum of unrelated behaviours that are consistent with a generally healthy lifestyle (e.g., vaccination), ${ }^{2}$ and in women treated with bisphosphonate, high adherence was associated to bone
Correspondence: Gérard Reach

Direction Qualité, Hôpital Avicenne, APHP, 125 Route de Stalingrad, Bobigny 93000 , France

Tel +33660845325

Email gerard.reach@aphp.fr 
mineral density testing and different types of preventive testing (e.g., colonoscopy). ${ }^{3}$

In previous studies, one author of this study demonstrated a link in the context of type 2 diabetes between adherence to medication and some character traits such as patience and obedience. ${ }^{4-8}$ Specifically, adherence was found to be more frequent in people who declared that they would prefer to receive $€ 1500$ in 1 year than $€ 500$ today (patience) and that they used to fasten their seatbelts when seated in the back of a car (obedience).

Gout is a chronic disorder, and its treatment is designed to maintain a serum uric acid level below $360 \mu \mathrm{mol} / \mathrm{L}(60 \mathrm{mg} / \mathrm{L})$. The treatment requires not only medications (urate-lowering therapy) but also lifestyle changes and weight loss in obese or overweight patients. ${ }^{9,10}$ The importance of non-pharmacological therapy in people with gout is justified by a number of arguments: (i) the prevalence of gout is associated to obesity, waist-to-hip ratio and weight gain; ${ }^{11}$ (ii) the prevalence of metabolic syndrome is increased in the presence of gout; ${ }^{12}$ (iii) in healthy individuals without a history of gout, the magnitude of insulin resistance is associated to serum uric acid concentration and inversely related to urinary uric acid clearance; urinary uric acid clearance is inversely related to serum uric acid concentration: ${ }^{13}$ these observations are therefore consistent with a hyperuricemic effect of insulin resistance, and losing weight and exercise fight against insulin resistance; (iv) hyperuricemia is associated with cardiovascular mortality. ${ }^{14}$ Therefore, lifestyle changes in gout are recommended in current guidelines, and lifestyle advice belongs to the indicators of quality of care in gout. ${ }^{15}$ Unfortunately, not all people with gout receive lifestyle change advice from their doctor, ${ }^{16}$ and there is some lack of interest for lifestyle changes from investigators. ${ }^{17}$ On the patient's side, it is well known that nonadherence to diet and exercise recommendations is in general even worse than nonadherence to medication. ${ }^{18}$

Published reviews and meta-analyses have indicated a high prevalence of nonadherence to drug therapy in people with gout, which has several consequences in relation to outcomes. ${ }^{19-22}$ It decreases the percentage of patients with controlled serum uric acid level, ${ }^{22}$ which increases the risk of gouty attacks ${ }^{23,24}$ and reduces the decrease in tophus size during treatment. ${ }^{25}$

In this context, this study investigated in people with gout the effects of patience and obedience on adherence to medication. Furthermore, if character traits do have a causal effect on adherence, it could be expected that different aspects of adherence (medication, dietary recommendations, exercise, smoking status and serum uric acid level monitoring) are linked. ${ }^{26}$ We therefore investigated whether they are associated in people with gout.

\section{Research Design And Methods Data Collection}

Data were obtained from a cross-sectional study performed in France between November 2014 and June 2015 that involved 630 general practitioners (GPs). The patients included were adults with gout who had been under longterm treatment for over 3 months. Medical data were collected by the GPs during a single visit, conducted under the usual conditions of medical practice. Patients completed during the appointment a self-report questionnaire, investigating general adherence to medication with five questions ${ }^{4}$ derived from the Girerd questionnaire ${ }^{27}$ and to alcohol and soda restrictions (Appendix). Patience was assessed using the patient's choice between two fictive monetary proposals: receiving $€ 1500$ in 1 year or $€ 500$ immediately. ${ }^{4}$ Obedience was evaluated with a single question assessing the use of the seatbelt in the rear seat of a car. ${ }^{6}$ Visual analogue scales and Likert scales were used to estimate adherence to advice relating to diet and physical activity, importance attributed to long-term treatment of gout, impact of gout on quality of life and life expectancy and satisfaction with the current treatment of gout. The perception of gout and its treatment were also evaluated using the Brief Illness Perception Questionnaire (B-IPQ). ${ }^{28}$

\section{Statistical Analysis}

SAS 9.4 software (SAS Institute Inc., Cary, NC) was used for the statistical analysis. For continuous data, the means and standard deviations were calculated. For categorical data, the frequency and percentage of the class level were calculated. Predictive factors for adherence to treatment and control serum uric acid level were evaluated with a $\chi^{2}$ test to compare ratios, a Student's $t$ test to compare continuous variables with a normal distribution, and nonparametric tests to compare continuous variables without a normal distribution. Multivariate analyses were performed using multivariate logistic regression. All the prognosis factors that were selected in the first step (univariate analyses with an alpha level of $25 \%$ so as not to miss any confounding or predictive factors) were included. If groups of selected factors are highly correlated, the most clinically relevant factors in each group of factors were selected to avoid collinearity problems. A backward elimination procedure was used. Verification of the confounding factor at each step 
was performed by calculating the percentage of variation in the estimated parameters with and without the removed candidate factor. If removing a nonsignificant factor changed by more than $20 \%$ of the estimated parameters, then it was kept in the model. The selection ceased when all the variables reached a significance level of $5 \%(P \leq 0.05)$ or were assigned confounding-factor status.

Multiple-correspondence analysis of the data was also performed using the following factors: adherence to medication, adherence to advice relating to practice of physical activity and to diet, regular measurement of serum uric acid, achievement of serum uric acid goal (latest available measurement), obedience (seatbelt fasteners vs nonfasteners), patience ( $€ 1500$ vs $€ 500)$, lifestyle changes, amount of alcohol drunk on an ordinary day, use of soda and beer, smoking status and whether a physician had given advice on lifestyle changes.

\section{Ethical Approval And Consent To Participate}

Before patient inclusion, the purpose and objectives of the study were explained orally and in writing to potential subjects, filling the self-questionnaire representing a written consent to participate. The written information given to the patients was included in the protocol submitted to the Advisory Committee on Information Processing in Material Research in the Field of Health (CCTIRS) and to the French Commission Nationale Informatique et Libertés, who gave their approval on 18 June 2014 and 29 October 2014, respectively.

\section{Role Of The Funding Source And Of The Corresponding Author}

The study was sponsored by Menarini. Euraxi Pharma was the contract research organisation appointed by the sponsor to conduct this study together with the academic authors GR, LM and RMF: from the design of the study and recruitment of the investigators to the initial data analysis. Statistical analyses were performed by GC at Capionis, a statistical consulting company whose data analyses are independent of the sponsor. No marketing or commercial representatives of the sponsor were involved in the recruitment of investigators. The sponsor gave its approval for submission of the article but was not involved in writing the report, which was performed by GR, the corresponding author. GR confirms that he had access to all the data for the study and was given final responsibility for the decision to submit for publication.

\section{Results \\ Characteristics Of Patients Included}

In total, 1875 patients were interviewed and the responses of 1441 were analysed; 434 (23.1\%) being excluded from the analysis due to absence of long-term treatment or missing data on adherence. As shown in Table 1, 84.6\% of the analysable patients were men, the mean age was 64.4 years, $85.1 \%$ of the patients were overweight, $38.4 \%$ were obese, and a high prevalence of hypertension, dyslipidaemia and type 2 diabetes was observed, with $17.0 \%$ of the patients combining the three. The on-going long-term treatment on the day of visit was febuxostat $(50.9 \%)$ or allopurinol $(49.7 \%)$. The regular measurement of serum uric acid was performed by $80.3 \%$ of the patients, and $41.9 \%$ of them were at the recommended goal $(\leq 360 \mu \mathrm{mol} / \mathrm{L})$ according to their last measurement.

The analysis of patients' self-questionnaires showed that $79.5 \%$ were adherent to medication, $62.2 \%$ stated that they complied with dietary advice and $45.2 \%$ followed directives on the practice of regular physical activity. Finally, $21.9 \%$ of the patients were smokers, $48.4 \%$ preferred to receive $€ 1500$ in 1 year in the fictive monetary scenario and $75.4 \%$ stated that they fastened their seatbelts when seated in the back seat of a car.

\section{Adherence To Medication: Association With Serum Uric Acid Outcome}

In univariate analysis, shown in Table 2, adherence to medication was associated with the regular measurement of serum uric acid (OR 1.486, 95\% CI [1.094-2.019], $P=0.011)$ and with achieving the goal for serum uric acid level (latest available measurement $\leq 360 \mu \mathrm{mol} / \mathrm{L}$ vs $>360$ $\mu \mathrm{mol} / \mathrm{L}$, OR 2.283, 95\% CI [1.641-3.178], $P<0.001)$.

\section{Adherence To Medication, Patience And Obedience} More adherent patients preferred to receive $€ 1500$ in 1 year $(52.7 \%)$ than nonadherent patients $(31.8 \%$, $P<0.001)$, and the percentage of patients who declared that they fastened their seatbelts when in the back of a car was also higher in adherent than in nonadherent patients $(78.8 \%$ vs $62.2 \%$, respectively, $P<0.001)$. These differences resulted in a univariate analysis with ORs of 2.383, 95\% CI [1.815-3.129], $P<0.001$ and 2.259, 95\% CI [1.713-2.978], $P<0.001$ for the relationship between adherence and patience and obedience, respectively. 
Table I Characteristics Of Patients

\begin{tabular}{|c|c|c|}
\hline Characteristics Of Patients & $\begin{array}{l}\text { Population } \\
\text { Of Analysis } \\
\text { ( } n=\mid 44 I)\end{array}$ & $\begin{array}{l}\text { Missing } \\
\text { Data }\end{array}$ \\
\hline $\begin{array}{l}\text { Gender } \\
\text { Male, n (\%) } \\
\text { Female, n (\%) }\end{array}$ & $\begin{array}{l}1213(84.6 \%) \\
22 \mid(15.4 \%)\end{array}$ & 8 \\
\hline $\begin{array}{l}\text { Age }(\text { mean } \pm \text { SD), years } \\
<60 \text { years, } n(\%) \\
{[60-70] \text { years, } n(\%)} \\
>70 \text { years, } n(\%)\end{array}$ & $\begin{array}{l}64.4 \pm 11.4 \\
446(31.5 \% \\
573(40.5 \%) \\
397(28.0 \%)\end{array}$ & 25 \\
\hline $\begin{array}{l}\text { Body mass index (mean } \pm \text { SD), } \mathbf{k g} / \mathrm{m}^{2} \\
\text { Overweight }\left(\mathrm{BMI}>25 \mathrm{~kg} / \mathrm{m}^{2}\right), \mathrm{n}(\%) \\
\text { Obesity }\left(\mathrm{BMI}>30 \mathrm{~kg} / \mathrm{m}^{2}\right)\end{array}$ & $\begin{array}{l}29.4 \pm 4.7 \\
1216(85.1 \%) \\
549(38.4 \%)\end{array}$ & 13 \\
\hline Family history of gout, $\mathbf{n}(\%)$ & $594(41.7 \%)$ & 18 \\
\hline Smokers, n (\%) & $313(21.9 \%)$ & 9 \\
\hline $\begin{array}{l}\text { Comorbidities } \\
\text { High blood pressure (HBP), n (\%) } \\
\text { Dyslipidaemia (DL), n (\%) } \\
\text { Type } 2 \text { diabetes (T2D), n (\%) } \\
\text { Renal impairment and/or lithiasis, n (\%) } \\
\text { Concomitant HBP, DL, T2D, n (\%) } \\
\text { Congestive heart failure, n (\%) } \\
\text { History of myocardial infarction, n (\%) } \\
\text { History of stroke, n (\%) }\end{array}$ & $\begin{array}{l}1005(70.1 \%) \\
881(61.8 \%) \\
3.5 \%) \\
195(13.5 \%) \\
245(17.0 \%) \\
76(5.3 \%) \\
51(3.5 \%) \\
33(2.3 \%)\end{array}$ & $\begin{array}{l}7 \\
16 \\
10 \\
0 \\
0 \\
0 \\
0 \\
0\end{array}$ \\
\hline $\begin{array}{l}\text { Number of acute attacks during the last } \\
\text { I } 2 \text { months (mean } \pm \text { SD), } \mathbf{n} \\
0-2 \text { attacks, } n(\%) \\
3-5 \text { attacks, } n(\%) \\
>5 \text { attacks }\end{array}$ & $\begin{array}{l}1.4 \pm 1.4 \\
1116(84.5 \%) \\
189(14.3 \%) \\
16(1.2 \%)\end{array}$ & 121 \\
\hline $\begin{array}{l}\text { Symptoms } \mathbf{s}^{\mathbf{a}} \mathbf{n}(\%) \\
\text { Pain and swelling } \\
\text { Podagra } \\
\text { Erythema } \\
\text { Tophus } \\
\text { Existence of sodium urate crystals } \\
\text { Renal lithiasis }\end{array}$ & $\begin{array}{l}1216(85.4 \%) \\
856(60.1 \%) \\
702(49.3 \%) \\
126(8.8 \%) \\
66(4.6 \%) \\
58(4.1 \%)\end{array}$ & 17 \\
\hline $\begin{array}{l}\text { Serum level of uric acid at time of } \\
\text { diagnosis (mean } \pm \text { SD), } \mu \mathrm{mol} / \mathrm{L}\end{array}$ & $511 \pm 76$ & 128 \\
\hline $\begin{array}{l}\text { Last measurement of serum level of uric } \\
\text { acid (mean } \pm \text { SD), } \mu \mathrm{mol} / \mathrm{L} \\
\leq 360 \mu \mathrm{mol} / \mathrm{L}, \mathrm{n}(\%) \\
>360 \mu \mathrm{mol} / \mathrm{L}, \mathrm{n}(\%)\end{array}$ & $\begin{array}{l}380 \pm 98 \\
465(41.9 \%) \\
645(58.1 \%)\end{array}$ & 331 \\
\hline $\begin{array}{l}\text { Regular measurement of serum level } \\
\text { uric acid } \\
\text { No, } n(\%) \\
\text { Yes, } n(\%)\end{array}$ & $\begin{array}{l}280(19.7 \%) \\
1138(80.3 \%)\end{array}$ & 23 \\
\hline $\begin{array}{l}\text { Ongoing long-term treatment on day of } \\
\text { visit }^{\text {a }} \\
\text { Febuxostat, } n(\%) \\
\text { Allopurinol, } n(\%)\end{array}$ & $\begin{array}{l}732(50.9 \%) \\
715(49.7 \%)\end{array}$ & 3 \\
\hline
\end{tabular}

(Continued)
Table I (Continued).

\begin{tabular}{|c|c|c|}
\hline Characteristics Of Patients & $\begin{array}{l}\text { Population } \\
\text { Of Analysis } \\
(n=\mid 44 I)\end{array}$ & $\begin{array}{l}\text { Missing } \\
\text { Data }\end{array}$ \\
\hline $\begin{array}{l}\text { Treatments prescribed at time of last } \\
\text { acute attack }\end{array}$ & & 28 \\
\hline Colchicine, n (\%) & $1,299(91.9 \%)$ & \\
\hline Analgesics, $\mathrm{n}(\%)$ & $666(47.1 \%)$ & \\
\hline $\begin{array}{l}\text { Nonsteroidal anti-inflammatory drugs, } \mathrm{n} \\
\text { (\%) }\end{array}$ & $480(34.0 \%)$ & \\
\hline Daily number of tablets (mean $\pm S D$ ), $n$ & $4.9 \pm 3.5$ & 11 \\
\hline$<5, \mathrm{n}(\%)$ & $776(54.3 \%)$ & \\
\hline $5-9, \mathrm{n}(\%)$ & $498(34.8 \%)$ & \\
\hline$\geq 10, \mathrm{n}(\%)$ & $156(10.9 \%)$ & \\
\hline $\begin{array}{l}\text { Lifestyle changes advised on day of visit } \\
\text { n (\%) }\end{array}$ & & 3 \\
\hline Avoiding animal products high in purine & 1017 (70.7\%) & \\
\hline Performing physical activity & $984(68.4 \%)$ & \\
\hline Losing weight & $944(65.6 \%)$ & \\
\hline Avoiding beer and alcoholic drinks & $914(63.6 \%)$ & \\
\hline $\begin{array}{l}\text { Avoiding drinks with high-fructose corn } \\
\text { syrup }\end{array}$ & $607(42.2 \%)$ & \\
\hline Stopping smoking & $25 I(17.5 \%)$ & \\
\hline None & $139(9.7 \%)$ & \\
\hline \multicolumn{3}{|l|}{ Adherence } \\
\hline Medication & 1145 (79.5\%) & 0 \\
\hline Diet & $891(62.2 \%)$ & 10 \\
\hline Exercise & $648(45.2 \%$ & 9 \\
\hline $\begin{array}{l}\text { Patience: preferring waiting for I year for } \\
€ I 500 \text { vs receiving } € 500 \text { today, } n \text { (\%) }\end{array}$ & $690(48.4 \%)$ & 14 \\
\hline $\begin{array}{l}\text { Obedience: being used to fasten seatbelt } \\
\text { when seated in a rear seat, } n(\%)\end{array}$ & $1072(75.4 \%)$ & 19 \\
\hline
\end{tabular}

Note: ${ }^{a}$ Several possible responses.

Abbreviation: SD, standard deviation.

\section{Adherence To Medication And Other Lifestyle Behaviours (Diet, Exercise And Smoking)}

We observed that more patients who were adherent to medication regimens complied with advice relating to diet $(65.9 \%$ vs $46.9 \%, P<0.001)$ and the practice of physical activity $(47.2 \%$ vs $37.0 \%, P=0.002)$ than nonadherent patients. This resulted in a univariate analysis that produced ORs of 2.190, 95\% CI [1.688-2.841], $P<0.001$, and $1.522,95 \%$ CI [1.169-1.983], $P=0.002$ for the relationship between adherence and compliance with diet and exercise, respectively. Furthermore, the number of glasses of alcoholic drinks on an ordinary day was lower in adherent patients ( 1 or 2 vs $>2$, OR 2.092, 95\% CI [1.610-2.718], $P<0.001)$, and an association with adherence to medication was also observed for the never vs regular consumption of soda (OR 2.516, 95\% CI [1.657-3.819], $P<0.001$ ) or of 
Table 2 Factors Associated With Adherence To Medication (Univariate Tests)

\begin{tabular}{|c|c|c|c|c|}
\hline Factor & Modalities & OR $[95 \% \mathrm{CI}]$ & $\boldsymbol{P}$ & Global $P$ \\
\hline Age (years) & $\begin{array}{l}{[60-70] \text { vs. }<60} \\
>70 \text { vs. }<60\end{array}$ & $\begin{array}{l}\text { I.190[0.883; } 1.603] \\
\text { I. } 434[1.022 ; 2.01 \mathrm{I}]\end{array}$ & $\begin{array}{l}0.253 \\
0.037\end{array}$ & 0.111 \\
\hline Gender & Female vs. male & $1.039[0.726 ; 1.486]$ & 0.835 & \\
\hline BMI $\left(\mathrm{kg} / \mathrm{m}^{2}\right)$ & $\begin{array}{l}\leq 25 \text { vs. }>30 \\
{[25-30] \text { vs. }>30}\end{array}$ & $\begin{array}{l}\text { I.5II [0.995; } 2.296] \\
\mathrm{I} .148[0.872 ; 1.513]\end{array}$ & $\begin{array}{l}\mathbf{0 . 0 5 3} \\
0.325\end{array}$ & 0.145 \\
\hline Tophus & Yes vs. No & $1.230[0.799 ; 1.894]$ & 0.348 & \\
\hline Renal disorder & Yes vs. No & $1.321[0.927 ; 1.882]$ & 0.124 & \\
\hline$H B P+T 2 D+D L$ & Yes vs. No & $1.363[0.987 ; 1.883]$ & 0.060 & \\
\hline History of myocardial infarction & Yes vs. No & $1.204[0.622 ; 2.329]$ & 0.582 & \\
\hline Existence of comorbidities & Yes vs. No & $1.142[0.883 ; 1.478]$ & 0.311 & \\
\hline Regular measurement of SUA level & Yes vs. No & $1.486[1.094 ; 2.019]$ & 0.011 & \\
\hline Number of acute attacks of gout during the last 12 months & $\begin{array}{l}>5 \text { vs. } \leq 2 \\
{[2-5] \text { vs. } \leq 2}\end{array}$ & $\begin{array}{l}0.377[0.136 ; 1.050] \\
0.538[0.380 ; 0.761]\end{array}$ & $\begin{array}{l}0.062 \\
<0.001\end{array}$ & $<0.001$ \\
\hline Information on lifestyle changes & Yes vs. No & $1.814[1.086 ; 3.028]$ & 0.023 & \\
\hline Daily number of tablets & Unit $=1$ & $0.950[0.917 ; 0.983]$ & 0.004 & \\
\hline Total B-IPQ score & Unit $=1$ & $0.929[0.914 ; 0.945]$ & $<0.001$ & \\
\hline Overall satisfaction with respect to long-term treatment for gout & Unit $=1$ & $1.296[1.218 ; 1.378]$ & $<0.001$ & \\
\hline Frequency of alcohol use & $\begin{array}{l}\text { Never vs. Regularly } \\
\text { Occasionally vs. Regularly }\end{array}$ & $\begin{array}{l}1.731[1.010 ; 2.966] \\
1.365[1.025 ; 1.817]\end{array}$ & $\begin{array}{l}0.046 \\
0.033\end{array}$ & 0.026 \\
\hline Number of glasses of alcoholic drink taken during an ordinary day & I or 2 vs. $>2$ & $2.092[1.610 ; 2.718]$ & $<0.001$ & \\
\hline Frequency of use of 6 or more standard glasses of alcoholic drink & $\begin{array}{l}\text { Never or < once/month vs. } \\
\text { Regularly }\end{array}$ & $2.489[1.906 ; 3.249]$ & $<0.001$ & \\
\hline Use of soda & $\begin{array}{l}\text { Never vs. Regularly } \\
\text { Occasionally vs. Regularly }\end{array}$ & $\begin{array}{l}2.516[1.657 ; 3.819] \\
1.597[1.081 ; 2.358]\end{array}$ & $\begin{array}{l}<0.001 \\
0.019\end{array}$ & $<0.001$ \\
\hline Use of beer & $\begin{array}{l}\text { Never vs. Regularly } \\
\text { Occasionally vs. Regularly }\end{array}$ & $\begin{array}{l}2.617[1.808 ; 3.787] \\
1.769[1.297 ; 2.412]\end{array}$ & $\begin{array}{l}<0.001 \\
<0.001\end{array}$ & $<0.001$ \\
\hline Smoking & No vs. Yes & $1.804[1.35 \mathrm{I} ; 2.408]$ & $<0.001$ & \\
\hline Achievement of serum uric acid goal (latest available measurement) & $\begin{array}{l}\leq 360 \mu \mathrm{mol} / \mathrm{L} \text { vs. }>360 \mu \mathrm{mol} / \mathrm{L} \\
>360 \mu \mathrm{mol} / \mathrm{L} \text { vs. Missing SUA data } \\
\leq 360 \mu \mathrm{mol} / \mathrm{L} \text { vs. Missing SUA data }\end{array}$ & $\begin{array}{l}2.283[1.641 ; 3.178] \\
1.032[0.759 ; 1.404] \\
2.357[1.623 ; 3.423]\end{array}$ & $\begin{array}{l}<0.001 \\
0.840 \\
<0.001\end{array}$ & $<0.001$ \\
\hline Long-term treatment with Febuxostat at time of inclusion & Yes vs. No & $1.462[1.130 ; 1.892]$ & 0.004 & \\
\hline Patience & Preferring $€ I 500$ in one year & $2.383[1.815 ; 3.129]$ & $<0.001$ & \\
\hline Obedience & Declaring fasting seatbelt & 2.259 [1.713; 2.978] & $<0.001$ & \\
\hline Compliance to diet advice & Yes vs. No & $2.190[1.688 ; 2.841$. & $<0.001$ & \\
\hline Compliance to exercise advice & Yes vs. No & $1.522[1.169 ; 1.983]$ & 0.002 & \\
\hline
\end{tabular}

Notes: Model of probability is "Adherence to long-term treatment = Yes". Bold data indicates significant data.

Abbreviations: OR, odds ratio comparing relative risk of being adherent based on modalities of the risk factors studied; $95 \% \mathrm{Cl}, 95 \%$ confidence interval of the OR; $\mathrm{P}$, probability that the OR is not different from I for the two modalities of risk factors tested (risk factors with more than two modalities); global P, probability that OR is not globally different from I for modalities of risk factors; B-IPQ, Brief IIlness Perception Questionnaire; HBP, high blood pressure; T2D, Type 2 diabetes; DL, dyslipidaemia; SUA, serum uric acid. 
beer (OR 2.617, 95\% CI [1.808-3.787], $P<0.001$ ). Finally, patients adherent to their medication regimen were more often nonsmokers (OR 1.804, 95\% CI [1.351-2.408], $P<0.001)$ and monitored their serum uric acid level more frequently (OR 1.486, 95\% CI [1.094-2.019], $P=0.011$ ).

\section{Analysis Of People With Missing Data For Recent Serum Uric Acid Level}

As shown in Table 1, there were in general little missing data, except for the last available serum uric acid level $(n=331$, i.e., $23 \%$ of the patients). In univariate analysis (Table 2 ), patients with these missing data were found to have the same risk of being adherent to medication than those with uncontrolled ( $>360 \mu \mathrm{mol} / \mathrm{L}$ ) serum uric acid levels (OR 1.032, 95\% CI [0.759-1.404], $P=0.840$ ) and they had a half as low risk of being adherent to medication than those with controlled $(\leq 360 \mu \mathrm{mol} / \mathrm{L})$ serum uric acid levels (OR 2.357, 95\% CI [1.623-3.423], $P<0.001)$.

In univariate analysis, the patients with missing data were found different from those for whom serum uric acid was available (Table 3 ) Their disease appeared less severe: absence of tophus $(P=0.009)$, of comorbidities $(P=0.002)$, lower daily tablet number $(P<0.001)$. They were less likely to adhere to medications $(P=0.028)$ and to advice on diet ( $P=0.005)$, alcohol and sodas $(P=0.005$ and $P=0.005$, respectively) and were more likely to smoke $(P=0.013)$.

\section{Factors Associated With Adherence To Medication (Multivariate Logistic Model)}

Eight factors were significantly associated with adherence to medication (Table 4): patience and obedience were among the determinants that were most strongly associated with adherence to medication regimen, with ORs of 2.056, 95\% CI [1.414-2.989], $P<0.001$, and 1.844, 95\% CI [1.273-2.671], $P=0.001$, respectively. The other determinants were compliance with diet advice and never vs regular consumption of soda (OR 1.706, 95\% CI [1.1972.429], $P=0.003$, and OR $1.899,95 \%$ CI [1.058-3.407], $P=0.032$, respectively), having a good perception of one's illness (B-IPQ score, $P<0.001$ ), being satisfied with one's long-term treatment of gout $(P=0.0016)$, age ( $>70$ vs $<60$, $P=0.014)$, and a lower daily number of pills $(P=0.039)$. The area under the receiver operating characteristic curve (AUC) was 0.767.

Table 5 shows data from the multivariate analyses when the 331 patients with unknown uric acid levels were included in the analysis. The results were essentially similar, except that not drinking soda regularly was not retained by the model. Here again, patience and obedience were found to be determinants of adherence to medication, with ORs of $1.894,95 \%$ CI [1.377-2.605], $P<0.001$, and $1.806,95 \%$ CI [1.310-2.490], $P<0.001$, respectively. The AUC was 0.756 .

\section{Obedience, Patience And Control Of Serum Levels Of Uric Acid}

In univariate analysis, obedience, but not patience, was found to be a determinant for achieving control of serum uric acid levels $(P<0.001$, Table 6$)$ together with adherence to medication, diet and exercise recommendations $(P<0.001)$. In multivariate analysis, obedience $(P=0.020)$, but not patience, was a determinant of this parameter together with compliance with diet advice $(P=0.007)$, compliance with exercise directives $(P=0.035)$, overall satisfaction with respect to long-term treatment of gout $(P<0.001)$, treatment with febuxostat at inclusion $(P<0.001)$, presence of tophus $(P=0.004)$ and the total B-IPQ score $(P=0.009)$ (Table 7, AUC 0.828).

\section{Clustering Between Different Aspects Of Adherence, Patience And Obedience}

The results of multiple-correspondence analyses, shown in Figure 1, illustrate the association between different aspects of adherence (medication, diet and exercise, smoking status and regular measurement of serum levels of uric acid), obedience and patience, and control of serum levels of uric acid, forming two separated clusters defining adherent and nonadherent patients.

Finally, a $\chi^{2}$ test demonstrated the existence of a link between patience and obedience $(P<0.001$, Table 8$)$.

\section{Discussion}

\section{Main Findings}

First, we observed that people with gout who were adherent to their medication regimens gave a patient answer more frequently to a fictive monetary choice, and they more frequently declared their habit to fasten their seatbelts while in the back of a car than nonadherent patients.

The meaning of these answers needs to be clarified. The implication of patience in the adherence to long-term therapies is consistent with the fact that the respective benefits of adherence and nonadherence in chronic diseases are often remote (preserving health, avoiding complications of the disease) and immediate (e.g., avoiding drug side effects), respectively. ${ }^{29,30}$ Thus, a fictive monetary choice (e.g., $€ 1500$ in 1 year vs $€ 500$ today) is an attempt to allow patients 
Table 3 Factors Associated With Missing Data Concerning Serum Uric Acid Measurement (Univariate Tests)

\begin{tabular}{|c|c|c|c|c|}
\hline Factor & Modalities & OR $[95 \% \mathrm{Cl}]$ & $\mathbf{P}$ & Global $P$ \\
\hline Age (years) & $\begin{array}{l}{[60-70] \text { vs. }<60} \\
>70 \text { vs. }<60\end{array}$ & $\begin{array}{l}0.776[0.580 ; 1.038] \\
0.778[0.565 ; 1.07 I]\end{array}$ & $\begin{array}{l}0.087 \\
0.123\end{array}$ & 0.165 \\
\hline Gender & Female vs. male & $1.076[0.768 ; 1.507]$ & 0.670 & \\
\hline BMI $\left(\mathrm{kg} / \mathrm{m}^{2}\right)$ & $\begin{array}{l}\leq 25 \text { vs. }>30 \\
{[25-30] \text { vs. }>30}\end{array}$ & $\begin{array}{l}0.966[0.660 ; 1.414] \\
1.027[0.785 ; 1.343]\end{array}$ & $\begin{array}{l}0.859 \\
0.846\end{array}$ & 0.945 \\
\hline Tophus & No vs. Yes & $2.012[1.188 ; 3.407]$ & 0.009 & \\
\hline Renal disorder & No vs. Yes & $1.678[1.119 ; 2.516]$ & 0.012 & \\
\hline$H B P+T 2 D+D L$ & No vs. Yes & $1.593[1.111 ; 2.284]$ & 0.011 & \\
\hline History of myocardial infarction & No vs. Yes & $1.088[0.552 ; 2.144]$ & 0.809 & \\
\hline Existence of comorbidities & No vs. Yes & $1.479[1.148 ; 1.906]$ & 0.002 & \\
\hline Regular measurement of SUA level & No vs. Yes & $147.12[93.043 ; 232.64]$ & $<0.001$ & \\
\hline Number of acute attacks of gout during the last 12 months & $\begin{array}{l}\leq 2 \text { vs }>5 \\
{[2-5] \text { vs. } \leq 2}\end{array}$ & $\begin{array}{l}0.818[0.26 I ; 2.558] \\
1.079[0.333 ; 3.50 I]\end{array}$ & $\begin{array}{l}0.729 \\
0.899\end{array}$ & 0.295 \\
\hline Information on lifestyle changes & Yes vs. No & $1.046[0.693 ; 1.579]$ & 0.830 & \\
\hline Daily number of tablets & Unit $=1$ & $0.932[0.896 ; 0.970]$ & $<0.001$ & \\
\hline Total B-IPQ score & Unit=I & $1.005[0.990 ; 1.019]$ & 0.524 & \\
\hline $\begin{array}{l}\text { Overall satisfaction with respect to long-term treatment } \\
\text { for gout }\end{array}$ & Unit $=1$ & $0.952[0.899 ; 1.009]$ & 0.096 & \\
\hline Frequency of alcohol use & $\begin{array}{l}\text { Occasionally vs. Never } \\
\text { Regularly vs. Never }\end{array}$ & $\begin{array}{l}1.024[0.634 ; 1.656] \\
0.968[0.611 ; 1.532]\end{array}$ & $\begin{array}{l}0.922 \\
0.888\end{array}$ & 0.916 \\
\hline $\begin{array}{l}\text { Number of glasses of alcoholic drink taken during an } \\
\text { ordinary day }\end{array}$ & $>2$ vs 1 or 2 & $1.427[1.115 ; 1.828]$ & 0.005 & \\
\hline $\begin{array}{l}\text { Frequency of use of } 6 \text { or more standard glasses of } \\
\text { alcoholic drink }\end{array}$ & $\begin{array}{l}\text { Regularly vs. Never or }<\text { once/ } \\
\text { month }\end{array}$ & $1.645[1.267 ; 2.135]$ & $<0.001$ & \\
\hline Use of soda & $\begin{array}{l}\text { Occasionally vs. Never } \\
\text { Regularly vs. Never }\end{array}$ & $\begin{array}{l}1.474[1.125 ; 1.931] \\
1.568[1.027 ; 2.394]\end{array}$ & $\begin{array}{l}0.005 \\
0.037\end{array}$ & 0.011 \\
\hline Use of beer & $\begin{array}{l}\text { Occasionally vs. Never } \\
\text { Regularly vs. Never }\end{array}$ & $\begin{array}{l}1.282[0.955 ; 1.722] \\
1.393[0.974 ; 1.993]\end{array}$ & $\begin{array}{l}0.099 \\
0.069\end{array}$ & 0.141 \\
\hline Smoking & Yes vs. Never & $1.433[1.078 ; 1.905]$ & 0.013 & \\
\hline Adherence to medication & No vs. yes & 1.387 [1.037; 1.855$]$ & 0.028 & \\
\hline $\begin{array}{l}\text { Long-term treatment with Febuxostat at time of } \\
\text { inclusion }\end{array}$ & No vs. Yes & $1.246[0.974 ; 1.594]$ & 0.080 & \\
\hline Patience & $\begin{array}{l}\text { Preferring } € 500 \text { now vs } € 1500 \text { in } \\
\text { one year }\end{array}$ & $1.134[0.885 ; 1.452]$ & 0.322 & \\
\hline Obedience Declaring fasting seatbelt & No vs. Yes & $0.965[0.723 ; 1.287]$ & 0.808 & \\
\hline Compliance to diet advice & No vs. Yes & $1.427[1.111 ; 1.832]$ & 0.005 & \\
\hline Compliance to exercise advice & No vs. Yes & $0.90 \mathrm{I}[0.704 ; \mathrm{I} .153]$ & 0.406 & \\
\hline
\end{tabular}

Notes: Model of probability is "Missing data concerning serum uric acid = Yes". Bold data indicates significant data. 
Table 4 Factors Associated With Adherence To Medication (Multivariate Logistic Model)

\begin{tabular}{|c|c|c|c|c|}
\hline Factor & Modalities & OR $[95 \% \mathrm{Cl}]$ & $P$ & Global $P$ \\
\hline \multirow[t]{2}{*}{ Age (years) } & {$[60-70]$ vs $<60$} & $1.444[0.954-2.184]$ & 0.082 & 0.042 \\
\hline & $>70$ vs $<60$ & $1.88 \mathrm{I}[1.137-3.1 \mathrm{II}]$ & 0.014 & \\
\hline Daily number of tablets & Unit $=1$ & 0.950 [0.904-0.997] & 0.039 & \\
\hline Total B-IPQ score & Unit $=1$ & $0.947[0.925-0.969]$ & $<0.001$ & \\
\hline $\begin{array}{l}\text { Overall satisfaction with respect to long-term } \\
\text { treatment of gout }\end{array}$ & Unit $=1$ & I.197 [1.099-1.303] & $<0.001$ & \\
\hline \multirow[t]{2}{*}{ Use of soda } & Never vs regularly & $1.899[1.058-3.407]$ & 0.032 & 0.035 \\
\hline & Occasionally vs regularly & $1.182[0.697-2.004]$ & 0.535 & \\
\hline Patience & Preferring $€ I 500$ in I year & $2.056[1.4 \mid 4-2.989]$ & $<0.001$ & \\
\hline Obedience & $\begin{array}{l}\text { Declaration of preference for fastening } \\
\text { seatbelt }\end{array}$ & $\mathrm{I} .844[1.273-2.67 \mid]$ & 0.001 & \\
\hline Compliance with diet advice & & $1.706[1.197-2.429]$ & $<0.001$ & \\
\hline
\end{tabular}

Notes: This table shows data based on patients without missing data $(n=952)$. Bold data indicates significant data.

Table 5 Factors Associated With Adherence To Medication (Multivariate Logistic Model)

\begin{tabular}{|c|c|c|c|c|}
\hline Factor & Modalities & OR $[95 \% \mathrm{Cl}]$ & $\mathbf{P}$ & Global P \\
\hline \multirow[t]{2}{*}{ Age (years) } & {$[60-70]$ vs $<60$} & $1.292[0.908-1.839]$ & 0.154 & 0.004 \\
\hline & $>70$ vs $<60$ & $2.077[1.350-3.195]$ & $<0.001$ & \\
\hline Daily number of pills & Unit $=1$ & $0.948[0.908-0.990]$ & 0.016 & \\
\hline Total B-IPQ score & Unit $=1$ & $0.946[0.928-0.964]$ & $<0.001$ & \\
\hline $\begin{array}{l}\text { Overall satisfaction with long-term treatment of } \\
\text { gout }\end{array}$ & Unit $=1$ & 1.205 [1.120-1.297] & $<0.001$ & \\
\hline Patience & Preferring $€ I 500$ in I year & $1.894[1.377-2.605]$ & $<0.001$ & \\
\hline Obedience & $\begin{array}{l}\text { Declaration of preference for fastening } \\
\text { seatbelt }\end{array}$ & $1.806[1.310-2.490]$ & $<0.001$ & \\
\hline Compliance with diet advice & Yes & $1.868[1.378-2.533]$ & $<0.001$ & \\
\hline
\end{tabular}

Notes: This table shows data where patients with missing data on the most recent measured serum levels of uric acid level were included in the analysed population (n 1204). Bold data indicates significant data.

to represent this "intertemporal choice", assuming that there is a correlation between preferences in financial and health domains. ${ }^{31}$ The seatbelt behaviour question centres on another health behaviour intended to indirectly protect the respondent, and, indeed, fastening seatbelt behaviour was found in this study to be associated with health preventive practices. ${ }^{32}$ However, concerning more specifically the rear seat, the intention to be obedient to the law may also cause this behaviour, ${ }^{33}$ in fact, some may refuse to fasten their seatbelts, manifesting reactance, i.e., a resistance that arouses in people when they consider that their freedom is threatened. $^{34}$ In a previous study of people with type 2 diabetes, we observed a link between reactance and nonadherence to medication. ${ }^{7}$

A link between patience and adherence to medication was observed in patients with type 2 diabetes ${ }^{4-8}$ and asthma, ${ }^{35}$ whereas impatience was found to be associated with obesity, ${ }^{36}$ overweight $^{37}$ and various addictions. ${ }^{38} \mathrm{~A}$ link between obedience, assessed by this seatbelt question, and adherence to medication was also observed in people with type 2 diabetes in two independent studies. ${ }^{6,7}$ Here, the two traits of character patience and obedience were investigated simultaneously in a single study for the first time, and both were found to be strong determinants of 
Table 6 Factors Associated With Controlled Serum Uric Acid Levels (Univariate Tests)

\begin{tabular}{|c|c|c|c|c|}
\hline Factor & Modalities & OR $[95 \% \mathrm{Cl}]$ & $P$ & Global $P$ \\
\hline Age (years) & $\begin{array}{l}{[60-70] \text { vs }<60} \\
>70 \text { vs }<60\end{array}$ & $\begin{array}{l}1.198[0.896-1.603] \\
1.451[1.059-1.989]\end{array}$ & $\begin{array}{l}0.223 \\
0.021\end{array}$ & 0.068 \\
\hline Gender & Female vs male & $0.878[0.626-1.228]$ & 0.447 & \\
\hline BMI $\left(\mathrm{kg} / \mathrm{m}^{2}\right)$ & $\begin{array}{l}\leq 25 \text { vs }>30 \\
{[25-30] \text { vs }>30}\end{array}$ & $\begin{array}{l}1.438[0.999-2.069] \\
1.341[1.031-1.744]\end{array}$ & $\begin{array}{l}0.051 \\
\mathbf{0 . 0 2 9}\end{array}$ & 0.046 \\
\hline Tophus & Yes vs no & $2.028[1.308-3.145]$ & 0.002 & \\
\hline Renal disorder & Yes vs no & $1.083[0.772-1.5 \mid 8]$ & 0.645 & \\
\hline $\mathrm{HBP}+\mathrm{T} 2 \mathrm{D}+\mathrm{DL}$ & Yes vs no & $0.987[0.725-1.342]$ & 0.932 & \\
\hline History of myocardial infarction & Yes vs no & $0.877[0.465-1.654]$ & 0.685 & \\
\hline Existence of comorbidities & Yes vs no & $0.914[0.720-1.162]$ & 0.464 & \\
\hline Regular measurement of serum uric acid & Yes vs no & $4.825[1.673-13.916]$ & 0.004 & \\
\hline Number of acute attacks of gout & $>5$ vs $\leq 2$ & $0.254[0.055-1.168]$ & 0.078 & $<0.001$ \\
\hline During the last 12 months & {$[2-5]$ vs $\leq 2$} & $0.428[0.285-0.642]$ & $<0.001$ & \\
\hline Information on lifestyle changes & Yes vs no & $2.091[1.393-3.139]$ & $<0.001$ & \\
\hline Daily number of tablets & Unit $=1$ & $1.002[0.968-1.037]$ & 0.915 & \\
\hline Total B-IPQ score & Unit $=1$ & $0.944[0.930-0.959]$ & $<0.001$ & \\
\hline $\begin{array}{l}\text { Overall satisfaction with respect to long-term treatment } \\
\text { of gout }\end{array}$ & Unit $=1$ & $1.416[1.324-1.515]$ & $<0.001$ & \\
\hline Frequency of alcohol use & $\begin{array}{l}\text { Occasionally vs regularly } \\
\text { Never vs regularly }\end{array}$ & $\begin{array}{l}1.697[1.090-2.641] \\
1.605[1.236-2.082]\end{array}$ & $\begin{array}{l}0.019 \\
<0.001\end{array}$ & $<0.001$ \\
\hline Number of glasses of alcohol taken during an ordinary day & I or 2 vs $>2$ & $1.852[1.449-2.368]$ & $<0.001$ & \\
\hline Frequency of drinking six or more standard glasses of alcohol & Never or $<$ once/month vs regularly & $1.705[1.287-2.259]$ & $<0.001$ & \\
\hline Consumption of soda & $\begin{array}{l}\text { Never vs regularly } \\
\text { Occasionally vs regularly }\end{array}$ & $\begin{array}{l}2.028[1.286-3.199] \\
1.799[1.147-2.823]\end{array}$ & $\begin{array}{l}0.002 \\
0.011\end{array}$ & 0.010 \\
\hline Consumption of beer & $\begin{array}{l}\text { Never vs regularly } \\
\text { Occasionally vs regularly }\end{array}$ & $\begin{array}{l}2.241[1.553-3.233] \\
2.045[1.452-2.880]\end{array}$ & $\begin{array}{l}<0.001 \\
<0.001\end{array}$ & $<0.001$ \\
\hline Smoking & No vs yes & $1.566[1.151-2.130]$ & 0.004 & \\
\hline $\begin{array}{l}\text { Long-term treatment with } \\
\text { febuxostat at time of inclusion }\end{array}$ & Yes vs no & $7.922[5.996-10.467]$ & $<0.001$ & \\
\hline Patience & Preferring $€ I 500$ in I year & $1.214[0.955-1.543]$ & 0.113 & \\
\hline Obedience & $\begin{array}{l}\text { Declaration of preference for fastening } \\
\text { seatbelt }\end{array}$ & $1.827[1.366-2.444]$ & $<0.001$ & \\
\hline $\begin{array}{l}\text { Adherence to medication prescription Adherent vs } \\
\text { nonadherent }\end{array}$ & & $2.283[1.64 \mid-3.178]$ & $<0.001$ & \\
\hline Compliance with dietary advice & Yes vs. No & $2.246[1.730-2.916]$ & $<0.001$ & \\
\hline Compliance with exercise advice & Yes vs. No & $1.666[1.308-2.122]$ & $<0.001$ & \\
\hline
\end{tabular}

Notes: Model of probability is "last serum uric acid level is $\leq 360 \mu \mathrm{mol} / \mathrm{L}=$ Yes". Bold data indicates significant data. 
Table 7 Factors Associated With Controlled Uric Acid Levels (Multivariate Logistic Model)

\begin{tabular}{|c|c|c|c|}
\hline Factor & Modalities & OR $[95 \% \mathrm{Cl}]$ & $\mathbf{P}$ \\
\hline Presence of tophus & No vs yes & $2.321[1.307-4.122]$ & 0.004 \\
\hline Total B-IPQ score & Unit $=1$ & $0.975[0.957-0.994]$ & 0.009 \\
\hline Overall satisfaction with respect to long-term treatment of gout & Unit $=1$ & $1.258[1.156-1.368]$ & $<0.001$ \\
\hline Treatment by febuxostat at inclusion & Yes vs no & $8.019[5.742-11.200]$ & $<0.001$ \\
\hline Obedience (seatbelt) & Yes vs no & $1.583[1.076-2.330]$ & 0.020 \\
\hline Compliance with diet & Yes vs no & $1.614[1.141-2.284]$ & 0.007 \\
\hline Compliance with advice for physical activity & Yes vs no & $1.434[1.025-2.007]$ & 0.035 \\
\hline
\end{tabular}

Notes: This table shows data based on patients without missing data $(n=936)$. Bold data indicates significant data.

adherence to medication in multivariate analyses (Tables 4 and 5). Obedience was found to be an independent determinant of achievement for the control of serum levels of uric acid in multivariate analyses (Table 7). In the same vein, we observed in another study in people with diabetes a link between obedience, as determined by the seatbelt question, and HbAlc. ${ }^{6}$

Secondly, this study also provided strong evidence that different aspects of adherence (medication, compliance with dietary, alcohol, soda and beer recommendations, exercise practices, smoking status and regular screening of serum uric acid levels) were linked; this was shown both in the univariate analyses of adherence to medication (Table 2) and in multiple-correspondence analyses

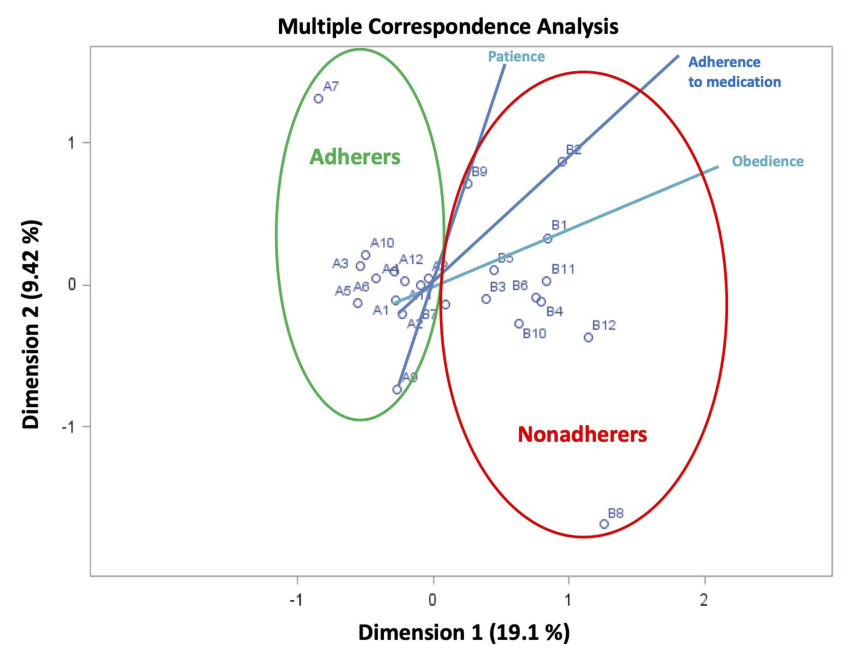

Figure I Nonadherence as a syndrome. AI: obedience (fastening seatbelt): yes; $\mathrm{BI}$ : no. A2: adherence to medication: yes; B2: no. A3: achieving goal for serum uric acid (latest available measurement, $\leq 360 \mu \mathrm{mol} / \mathrm{L}$ vs $>360 \mu \mathrm{mol} / \mathrm{L}$ ): yes; B3: no. A4: nonsmoker; B4: smoker. A5: compliance with directives on exercise: yes; B5: no. A6: compliance with diet recommendations: yes; B6: no. A7: lifestyle instructions given by the doctor: yes; $B 7:$ no. A8: regular measurements of serum uric acid level: yes; B8: no. A9: patience (preferring to receive $€ 1500$ in I year): yes; B9: impatience (preferring to receive $€ 500$ today). Al0: I or 2 glasses of alcohol on an ordinary day; BI0: >2 glasses of alcohol. All: consumption of soda only occasionally or never; $\mathrm{BI}$ I: regular consumption of soda. $\mathrm{AI} 2$ : consumption of beer only occasionally or never; $\mathrm{B}$ 12: regular consumption of beer.
(Figure 1). This clustering was expected if character traits do have real causal effects on adherence.

Finally, this study, which investigated the effects of patience and obedience simultaneously for the first time, provided evidence that these traits, as defined in this study, are linked (Table 8). This link may be caused by the fact that the seatbelt question is not specific for obedience and may also be influenced by the patient's relationship to temporality. However, it is tempting to speculate that patience and obedience represent the manifestations of two related brain executive functions that are by and large located in the prefrontal cortex. This speculation is consistent with the hypothesis that the lack of maturation of these two functions in adolescents ${ }^{39,40}$ explains the frequent nonadherence and risk-taking observed at this age.

\section{Strengths And Limitations Of The Study}

One of the strengths of this study is the consistency exhibited between the data presented here and those previously observed in different patient populations and in different settings, ${ }^{4-8}$ which is reassuring regarding their respective validities and generalisability. In addition, this study's originality lay in its simultaneous testing of the involvement of the two traits of character. Moreover, it provided a detailed analysis of adherence to diet prescriptions, allowing a link to be demonstrated between adherence to medication and lifestyle changes.

In general, there were little missing data, except for the last measurement of serum uric acid level $(\mathrm{n}=331)$. Interestingly, the data shown in Table 2 indicate that people with missing data had a half as low risk of being adherent to medication than controlled patients. Actually, data presented in Table 3 indicate that they had fewer gout complications and comorbidities than people in whom serum uric acid data were available. This disease characteristics may explain the lack of serum uric acid measurement since data 
Table 8 Patience And Obedience Relationship

\begin{tabular}{|c|c|c|c|c|}
\hline & & \multicolumn{3}{|l|}{ Obedience } \\
\hline & & Yes $(N=1073)$ & No $(N=350)$ & $P$ value Yes Vs No \\
\hline Patience & $\begin{array}{l}\text { Yes } \\
\text { No } \\
\text { Missing data }\end{array}$ & $\begin{array}{l}553(51.8 \%) \\
514(48.2 \%) \\
6\end{array}$ & $\begin{array}{l}134(38.5 \%) \\
2 \mid 4(61.5 \%) \\
2\end{array}$ & $<0.001$ \\
\hline
\end{tabular}

Notes: Patience: answer of $€ I 500$ to the question: "Imagine that one day you were offered $€ 500$ now or $€ I 500$ in I year: which would you choose?" Obedience: answer Yes to "do you fasten your seatbelt when seated in the back seat of a car?" Bold data indicates significant data.

missing was not associated with patience or obedience. Importantly, we checked that including these patients with missing data in the multivariate analyses had essentially no effect on the demonstration of the determining effects of patience and obedience on adherence to medication (Table 5).

The main limitation of this study is the relative value of the data, which relied on self-report questionnaires and not on the direct observation of patients' behaviours. Thus, the associations found for different aspects of nonadherence (i.e., to medication and to lifestyle change) may be simply due to the fact that patients gave similar answers to similar questions. In addition, patients were interviewed at the doctor's appointment. Thus, although their names were not mentioned in the questionnaire, they may have given socially desirable answers.

More specifically, the assessment of adherence through questionnaires and interviews is in general less robust than direct measurements (pharmacy records or pill counts). This cohort presented a higher adherence to medical therapy (almost 80\%) than other representative data available in the literature: gout is the chronic illness for which adherence to treatment is the lowest. ${ }^{19}$ However, a recent meta-analysis found a mean rate of adherence of $63 \%$, as assessed in interviews, with a $95 \%$ CI of $42 \%-83 \%{ }^{20}$ These assessments have therefore only a relative value. Finally, the evaluation of patient adherence in this study relied on a five-item questionnaire that was not formally validated. Nevertheless, the fact that adherence to medication was found to be significantly associated with age, ${ }^{3,19}$ and with controlled serum levels of uric acid suggests that this questionnaire may have at least some value as a marker of adherence. Incidentally, the same questionnaire utilised here was also used in our study of people with type 2 diabetes, in which adherence was found to be associated with achievement of control of HbAlc level. ${ }^{4}$

Finally, the percentage of patients under febuxostat therapy in this study was rather high and may not reflect general gout treatment. No marketing or commercial representatives of the sponsor, who commercialises this new drug, were involved in the recruitment of investigators, which was organised by Euraxi Pharma, the contract research organisation appointed by the sponsor. However, this does not rule out a recruitment bias, linked to the fact that the GPs who participated in the study had a large active file of patients with gout and may have received Menarini reps recently, explaining a high rate of febuxostat prescription. $^{41}$ Nevertheless, we do not think that this possible bias changes the main conclusions of this study, the aim of which was to investigate the reasons of adherence to drugs in general. Incidentally, we observed that febuxostat led to better adherence than allopurinol (Table 2, OR $1.462[1.130 ; 1.892], P=0.004$ ) and seemed to have a better efficacy in achieving serum uric acid control (Table 6, OR 7.922 [5.996-10.467], $P<0.001$ ). This superiority of febuxostat in achieving serum uric acid control is consistent with other data from the literature. For instance, Cutolo et al observed in a randomised study that febuxostat showed a higher probability to achieve the recommended target serum uric acid concentration than allopurinol (odds ratio: 2.43 [95\% CI: 2.1192.789] and 4.05 [95\% CI: 3.41-4.82] for serum uric acid levels $<6 \mathrm{mg} / \mathrm{dL}$ and $\leq 5 \mathrm{mg} / \mathrm{dL}$, respectively. ${ }^{42}$

\section{Conclusion: Character Traits, Patients' Preferences And Nonadherence As A Syndrome}

The determinants of nonadherence to medication are complex, involving factors linked to the nature of the disease, nature of treatment, social context and the psychology of the patient. ${ }^{1}$ For people with gout, a study showed the provocative fact that using non-steroidal anti-inflammatory drugs within the year before treatment initiation was predictive of nonadherence to urate-lowering therapy (OR, 1.15; 95\% CI, $1.00-1.31$ ), refuting the intuitive hypothesis that active gout responsible for severe pain would improve adherence, ${ }^{43}$ in accordance with the idea that nonadherence is more frequent 
in silent diseases. Evidently, nonadherence is a complex issue, since we observed in this study that people with less severe gout are also nonadherent to medication (Table 3 ).

The first main conclusion of this study is that it extends to gout the consideration that among other psychological factors, character traits, specifically patience and obedience, are associated with adherence to long-term therapies, suggesting that this link between character traits and adherence is not specific to a given disease. Second, we propose that the involvement of character traits explains, at least in part, that the different aspects of adherence, medication and lifestyle (diet, exercise, alcohol and smoking status) are often linked together, ${ }^{2,3,44,45}$ as illustrated in multiple-correspondence analyses (Figure 1).

Therefore, these observations suggest that nonadherence to treatment is a syndrome. This study provides empirical verification of a hypothesis suggesting, on the basis of essentially philosophical arguments, that different aspects of adherence or nonadherence are interconnected by common causal mechanisms. ${ }^{26,30}$ This phenomenology of adherence is especially visible in a disease such as gout, the treatment of which requires, as with diabetes, both a medication regimen and lifestyle changes. ${ }^{10-18}$ Incidentally, since the lack of data on serum uric acid was found linked to nonadherence to medication prescriptions and to advice on diet, alcohol and soda, and to smoking, we propose that lack of disease monitoring be included in the nonadherence syndrome. This is consistent with the general observation that patients who are nonadherent to their medication regimens are less likely to perform lab analyses. ${ }^{2,3}$

This interpretation clarifies also the enigmatic fact that, in randomised clinical trials, patients allocated to placebo consistently exhibit a higher survival rate when they are adherent, ${ }^{46,47}$ leading to explanations using the "healthy adherer" concept for this fascinating observation. ${ }^{46}$ The data reported herein support this explanation by demonstrating a strong link between adherence to medication and dietary and exercise recommendations and other protective behaviours. We suggest that character traits such as patience and obedience and, possibly, others such as fidelity to habits, optimism, joy and caution ${ }^{29}$ have a real causal effect, leading, when they are present, to a "healthy adherer" phenotype. By "real causal effect", we mean that it is not only a statistical link between observations but a mechanism, in the same sense that insulin causes a decrease in blood glucose concentration. ${ }^{26,30}$ The absence of these positive character traits leads to conditions of what we propose to dub a "nonadherence syndrome": patience and obedience may be encompassed in the more general concept of cautious behaviour (avoidance of risks), which has been found by us $^{7}$ and others ${ }^{48}$ to be linked to adherence in people with diabetes.

Finally, recognising the causal effects of character traits on the occurrence of nonadherence may in part explain the relative failure of interventions intended to improve adherence. ${ }^{49}$ Moreover, this new concept may have important ethical implications because character traits shape patients' preferences, which are a central part of shared decision-making. ${ }^{50}$

\section{Acknowledgments}

The authors thank Enago for the English language review. They express their gratitude to the general practitioners who participated in this study.

\section{Author Contributions}

All authors contributed to data analysis, drafting or revising the article, gave final approval of the version to be published, and agree to be accountable for all aspects of the work. More specifically, GR, LM, RMF, PM and IEB were involved in designing the study protocol, coordinating the study, and analysing the results. GC performed the statistical analysis. GR designed and supervised the specific analysis of the implication of character traits in adherence presented in this report and wrote the manuscript.

\section{Disclosure}

GR, LM and RMF received fees from Menarini to design the study and to analyse the results. IEB and PM are Menarini employees. GC is an employee of Capionis. The authors report no other conflicts of interest in this work.

\section{References}

1. WHO. Adherence to Long-Term Therapies. Evidence for Action. Geneva: World Health Organization; 2003.

2. Brookhart MA, Patrick AR, Dormuth C, et al. Adherence to lipidlowering therapy and the use of preventive health services: an investigation of the healthy user effect. Am J Epidemiol. 2007;166:348-354. doi:10.1093/aje/kwm070

3. Curtis JR, Xi J, Westfall AO, et al. Improving the prediction of medication compliance: the example of bisphosphonates for osteoporosis. Med Care. 2009;47:334-341. doi:10.1097/MLR.0b013e31818afa1c

4. Reach G, Michault A, Bihan H, Paulino C, Cohen R, Le Clesiau H. Patients' impatience is an independent determinant of poor diabetes control. Diabetes Metab. 2011;37:497-504. doi:10.1016/j.diabet.2011.03.004

5. Lebeau G, Consoli SM, Le Bouc R, et al. Delay discounting of gains and losses, glycemic control and therapeutic adherence in type 2 diabetes. Behav Processes. 2016;132:42-48. doi:10.1016/j.beproc.2016.09.006 
6. Reach G. Obedience and motivation as mechanisms for adherence to medication: a study in obese type 2 diabetic patients. Patient Prefer Adherence. 2011;5:523-531.

7. Reach G, Pellan M, Crine A, Touboul C, Ciocca A, Djoudi Y. Holistic psychosocial determinants of adherence to medication in people with type 2 diabetes. Diabetes Metab. 2018;S1262-3636(18) 30116-2. doi:10.1016/j.diabet.2018.06.001

8. Reach G, Boubaya M, Brami Y, Lévy V. Disruption in time projection and non-adherence to long-term therapies. Patient Prefer Adherence. 2018;12:2363-2375.

9. Richette P, Doherty M, Pascual E, et al. 2016 updated EULAR evidence-based recommendations for the management of gout. Ann Rheum Dis. 2017;76:29-42. doi:10.1136/annrheumdis-2016-209707

10. Choi HK. A prescription for lifestyle change in patients with hyperuricemia and gout. Curr Opin Rheumatol. 2010;22:165-172. doi:10.1097/BOR.0b013e328335ef38

11. Choi YK, Atkinson K, Karlson EW, et al. Obesity, weight change, hypertension, diuretic use, and risk of gout in men. The Health Professionals Follow-up Study. Arch Intern Med. 2005;165:742 -748. doi:10.1001/archinte.165.7.742

12. Choi HK, Ford ES. Prevalence of the metabolic syndrome in individuals with hyperuricemia. Am J Med. 2007;120:442-447. doi:10.1016/j.amjmed.2006.06.040

13. Facchini F, Chen YD, Hollenbeck CB, et al. Relationship between resistance to insulin-mediated glucose uptake, urinary uric acid clearance, and plasma uric acid concentration. JAMA. 1991;266:30083011. doi:10.1001/jama.1991.03470210076036

14. Choi HK, Curhan G. Independent impact of gout on mortality and risk for coronary heart disease. Circulation. 2007;116:894-900. doi:10.1161/CIRCULATIONAHA.107.703389

15. Mikuls TR, MacLean CH, Olivieri J, et al. Quality of care indicators for gout management. Arthritis Rheum. 2004;50:937-943. doi:10.1002/ (ISSN)1529-0131

16. Roddy E, Zhang W, Doherty M, et al. Concordance of the management of chronic gout in a UK primary-care population with the EULAR gout recommendations. Ann Rheum Dis. 2007;66:13111315. doi:10.1136/ard.2007.070755

17. Singh JA, Hodges JS, Toscano JP, et al. Quality of care for gout in the US needs improvement. Arthritis Rheum. 2007;57:822-829. doi:10.1002/(ISSN)1529-0131

18. McNabb WL. Adherence in diabetes: can we define it and can we measure it? Diabetes Care. 1997;20:216-218. doi:10.2337/diacare.20.2.215

19. Briesacher BA, Andrade SE, Fouayzi H, Chan KA. Comparison of drug adherence rates among patients with seven different medical conditions. Pharmacotherapy. 2008;28:437-443. doi:10.1592/phco.28.4.437

20. Yin R, Li L, Zhang G, et al. Rate of adherence to urate-lowering therapy among patients with gout: a systematic review and metaanalysis. BMJ Open. 2018;8(4):e017542. doi:10.1136/bmjopen-2017017542

21. Aung T, Myung G, FitzGerald JD. Treatment approaches and adherence to urate-lowering therapy for patients with gout. Patient Prefer Adherence. 2017;11:795-800. doi:10.2147/PPA

22. Reach G. Treatment adherence in patients with gout. Joint Bone Spine. 2011;78(5):456-459. doi:10.1016/j.jbspin.2011.05.010

23. Halpern R, Mody RR, Fuldeore MJ, et al. Impact of non compliance with urate-lowering drug on serum urate and gout-related healthcare costs: administrative claims analysis. Curr Med Res Opin. 2009;25:1711-1719. doi:10.1185/03007990903017966

24. Shoji A, Yamanaka H, Kamatani N. A retrospective study of the relationship between serum urate level and recurrent attacks of gouty arthritis: evidence for reduction of recurrent gouty arthritis with antihyperuricemic therapy. Arthritis Rheum. 2004;51:321-325. doi:10.1002/art.20405

25. Perez-Ruiz F, Calabozo M, Pijoan JI, et al. Effect of urate-lowering therapy on the velocity of size reduction of tophi in chronic gout. Arthritis Rheum. 2002;47:356-360. doi:10.1002/(ISSN)1529-0131
26. Reach G. A novel conceptual framework for understanding the mechanism of adherence to long term therapies. Patient Prefer Adherence. 2008;2:7-19.

27. Girerd X, Hanon O, Anagnostopoulos K, Ciupek C, Mourad JJ, Consoli S. Evaluation de l'observance du traitement anti-hypertenseur par un questionnaire: mise au point et utilisation dans un service spécialisé. Presse Med. 2001;30:1044-1048.

28. Broadbent E, Petrie KJ, Main J, Weinman J. The brief illness perception questionnaire. J Psychosom Res. 2006;60:631-637. doi:10.1016/ j.jpsychores.2005.10.020

29. Reach G. Temporality in chronic diseases and adherence to long-term therapies: from philosophy to science and back. Diabetes Metab. 2018;S1262-3636(18)30217-9. doi:10.1016/j.diabet.2018.11.002

30. Reach G. The Mental Mechanisms of Adherence to Long-Term Therapies, Mind and Care. Foreword by Pascal Engel. Philospohy and Medicine. Springer; 2015.

31. Fredslund EK, Mørkbak MR, Gyrd-Hansen D. Different domains Different time preferences? Soc Sci Med. 2018;207:97-105. doi:10.1016/j.socscimed.2018.04.052

32. Williams AF, Wechsler H. Interrelationship of preventive actions in health and other areas. Health Serv Rep. 1972;87:969-976. doi:10.2307/4594704

33. Mohamed N, Mohd Yusoff MF, Isah N, Othman I, Syed Rahim SA, Paiman N. Analysis of factors associated with seatbelt wearing among rear passengers in Malaysia. Int J Inj Contr Saf Promot. 2011;18:3-10. doi:10.1080/17457300.2010.487153

34. Brehm JW. A Theory of Psychological Reactance. New York: Academic Press; 1966.

35. Brandt S, Dickinson B. Time and risk preferences and the use of asthma controller medications. Pediatrics. 2013;131:e1204-e1210. doi:10.1542/peds.2011-2982

36. Weller RE, Cook EWIII, Aswar KB, Cox JE. Obese women show greater delay discounting than healthy-weight women. Appetite. 2008;51:563-569. doi:10.1016/j.appet.2008.04.010

37. Ikeda S, Kang MI, Ohtake F. Hyperbolic discounting, the sign effect, and the body mass index. J Health Econ. 2010;29:268-284 doi:10.1016/j.jhealeco.2010.01.002

38. Perry JL, Carroll ME. The role of impulsive behavior in drug abuse. Psychopharmacology. 2008;200:1-26. doi:10.1007/s00213-008-1173-0

39. Shulman EP, Smith AR, Silva K, et al. The dual systems model: review, reappraisal, and reaffirmation. Dev Cogn Neurosci. 2016;17:103-117. doi:10.1016/j.den.2015.12.010

40. Christakou A, Brammer M, Rubia K. Maturation of limbic corticostriatal activation and connectivity associated with developmental changes in temporal discounting. NeuroImage. 2010. doi:10.1016/j. neuroimage.2010.08.067

41. Gabbay J, Le May A. Evidence based guidelines or collectively constructed "mindlines?" Ethnographic study of knowledge management in primary care. BMJ. 2004;329:1013-1017. doi:10.1136/ bmj.329.7473.1013

42. Cutolo M, Cimmino MA, Perez-Ruiz F. Potency on lowering serum uric acid in gout patients: a pooled analysis of registrative studies comparing febuxostat vs. allopurinol. Eur Rev Med Pharmacol Sci. 2017;21:4186-4195.

43. Harrold LR, Andrade SE, Briesacher BA, et al. Adherence with urate-lowering therapies for the treatment of gout. Arthritis Res Ther. 2009;11:R46. doi:10.1186/ar2659

44. Ahmed AT, Karter AJ, Liu J. Alcohol consumption is inversely associated with adherence to diabetes self-care behaviours. Diabet Med. 2006;23:795-802. doi:10.1111/dme.2006.23.issue-7

45. Solberg LI, Desai JR, O'Connor PJ, et al. Diabetic patients who smoke: are they different? Ann Fam Med. 2004;2:26-32. doi:10. 1370/afm.36

46. Simpson SH, Eurich DT, Majumdar SR, et al. A meta-analysis of the association between adherence to drug therapy and mortality. BMJ. 2006;333(7557):15. doi:10.1136/bmj.38875.675486.55 
47. Pressman A, Avins AL, Neuhaus J, Ackerson L, Rudd P. Adherence to placebo and mortality in the Beta Blocker Evaluation of Survival Trial (BEST). Contemp Clin Trials. 2012;33(3):492-498. doi:10.10 16/j.cct.2011.12.003

48. Simon-Tuval T, Shmueli A, Harman-Boehm I. Adherence of patients with type 2 diabetes mellitus to medications: the role of risk preferences. Curr Med Res Opin. 2018;34:345-351. doi:10.1080/03007 995.2017.1397506
49. Sapkota S, Brien JA, Greenfield J, Aslani P. A systematic review of interventions addressing adherence to anti-diabetic medications in patients with type 2 diabetes - impact on adherence. PLoS One. 2015;10:e0118296. doi:10.1371/journal.pone.0118296

50. Emanuel EJ, Emanuel LL. Four models of the physician-patient relationship. JAMA. 1992;267:2221-2226. doi:10.1001/jama.1992. 03480160079038

\section{Publish your work in this journal}

Patient Preference and Adherence is an international, peer-reviewed, open access journal that focusing on the growing importance of patient preference and adherence throughout the therapeutic continuum. Patient satisfaction, acceptability, quality of life, compliance, persistence and their role in developing new therapeutic modalities and compounds to optimize clinical outcomes for existing disease states are major areas of interest for the journal. This journal has been accepted for indexing on PubMed Central. The manuscript management system is completely online and includes a very quick and fair peer-review system, which is all easy to use. Visit http:// www.dovepress.com/testimonials.php to read real quotes from published authors. 